\title{
ГЕОГРАФИЧЕСКАЯ И ОТРАСЛЕВАЯ СТРУКТУРА МИРОВЫХ ИНВЕСТИЦИОННЫХ ПОТОКОВ В КОНТЕКСТЕ МЕЖДУНАРОДНОГО ТЕХНОЛОГИЧЕСКОГО ОБМЕНА
}

\section{GEOGRAPHIC AND SECTORAL STRUCTURE OF GLOBAL INVESTMENT FLOWS IN THE CONTEXT OF INTERNATIONAL TECHNOLOGICAL EXCHANGE}

R. Gurkov

Summary. The article discusses the main trends, direction and sectoral cross-section of the world investment flows, as one of the main mechanisms of international technological exchange (technology transfer). The author analyzes world investment flows based on the statistical indicators of the outflows and inflows of FDI over the last thirty years. At the same time, the author analyzes the sectoral structure of FDI based on the available data on mergers and acquisitions. The author concludes that developing countries are building capacity and changing the direction of FDI from West-West and South-West to South-South and West-South. At the same time, the key industries receiving the largest volumes of $F D I$ are financial services, the oil and gas industry, telecommunications and electronics, the pharmaceutical industry, and software development.

Keywords: international technological exchange, technology transfer, global financial market, foreign direct investments, mergers and acquisitions, high-tech industry, technologies, developing countries, South-East Asia.
$\mathbf{M}$ еждународный технологический обмен - является комплексным процессом, осуществляемым в различных формах и с помощью различных механизмов [1].

В условиях развития рыночной экономики и торгово-экономических связей наибольший интерес представляет коммерческая форма международного технологического обмена, при которой разработчик (продавец) осуществляет передачу своей технологии (знания, технологического товара или наукоемкой услуги) потребителю (покупателю) за обусловленное в рамках договорно-правовых обязательств вознаграждение [2].

Основным условием осуществления данной формы технологического обмена выступает извлечение ком-
Гурков Родион Александрович

Аспирант, Всероссийская академия внешней торговли Министерства экономического развития

Российской Федерации; Ведущий советник отдела стран Юго-Восточной Азии и Океании Департамента стран Азии, Африки, Латинской Америки Минпромторга России gurkov_rodion@mail.ru

Аннотация. В статье рассматриваются основные тенденции, направленность и отраслевой срез мировых инвестиционных потоков, которые являются одним из основных механизмов международного технологического обмена. Автором проведен анализ мировых инвестиционных потоКов, построенный на статистических показателях оттоков и притоков ПиИ за последние тридцать лет. Одновременно автором анализируется отраслевая структура ПИИ на основе имеющихся данных по сделкам по слияниям и поглощениям. Автором делается вывод 0 наращивании потенциала развивающимися странами и изменению вектора направленности ПиИ с Запад-Запад и Юг-Запад на Юг-Юг и Запад-Юг. Вместе с тем, ключевыми отраслями в которые поступает наибольшие объемы ПИИ являются финансовые услуги, нефтегазовая промышленность, телекоммуникации и радиоэлектроника, фармацевтическая промышленность, создание программного обеспечения.

Ключевые слова: международный технологический обмен, мировые финансовый рынок, прямые иностранные инвестиции, слияния и поглощения, высокотехнологичная промышленность, технологии, развивающиеся страны, Юго-Восточная Азия.

мерческой выгоды (прибыли) разработчиком технологии, и выражается как в виде денежного эквивалента, так и опосредованно, путем модернизации своей разработки [3].

На сегодняшний день мировая практика одним из механизмов [4] коммерческого осуществления международного технологического обмена [5] выделяет прямые иностранные инвестиции (ПИИ) и сопровождающие их строительство, реконструкция, модернизация предприятий, а также создание совместных предприятий или сделки по слиянию и поглощению других предприятий с целью расширения и усиления бизнеса.

Трансграничное перемещение потоков инвестиционного капитала, основанное на эффективном между- 
народном сотрудничестве, приобретает все большее значение в контексте стабилизации и увеличении темпов роста экономики любой страны.

Потоки ПИИ являются вкладом иностранных хозяйствующих субъектов, которые могут осуществляться как в денежном, так и товарном эквиваленте.

По определению, взятому из руководства по платежному балансу и международной инвестиционной позиции Международного Валютного Фонда прямыми иностранными инвестициями называются инвестиции, вкладываемые в предприятия любой отрасли экономики, но только не в стране инвестора, целью которых является получение длительной прибыли. Задача инвестора также заключается в получении существенного права голоса в управлении иностранным предприятием [6]. Инвестором может осуществляться управление и влияние на деятельность компании, территориально расположенной в другой стране, в том случае, если в его собственности находится не менее $10 \%$ акций, имеющих право голоса [7].

Согласно определению, представленному в программных документах Организации экономического сотрудничества и развития (ОЭСР), прямыми иностранными инвестициями называется процесс по осуществлению резидентом одной страны (прямым инвестором) международных инвестиций в предприятие резидента другой страны (реципиента), отличной от страны инвестора, с целью достижения своих долгосрочных целей в отношении этого предприятия [8].

ПИИ определяются как инвестиции, отражающие устойчивый интерес и контроль со стороны прямого иностранного инвестора, резидента одной экономики, предприятия, резидента другой экономики (иностранного филиала).

«Приток ПИИ включает капитал, предоставленный прямым иностранным инвестором иностранному партнеру, или капитал, полученный прямым иностранным инвестором от иностранного партнера.

Отток прямых иностранных инвестиций представляет собой те же самые потоки с точки зрения другой экономики [9].

Прямые иностранные инвестиции являются вложениями, рассчитанными на долгосрочное взаимовыгодное сотрудничество партнеров. Данный механизм международного технологического обмена является одним из инструментов повышения производительности и технологичности предприятий.
«Иностранный инвестор приносит новые способы организации производственных процессов, новые технологии и обеспечивает себе доступ на рынок страны, куда осуществляет инвестирование [10].

В свою очередь государство, осуществляющее привлечение иностранного капитала в свою экономику, устраняет имеющийся инвестиционный «голод», содействуя расширению инвестиционных процессов, поднятию и оживлению экономики, передаче опыта и обучению новым, ранее не имеющимся, технологическим процессам научно-технический персонал, стимуляции развития производственных мощностей; устранению безработицы и повышении уровня доходов населения, а также увеличению доли экономически эффективного человеческого капитала.

С целью выявления ключевых географических направлений мировых инвестиционных потоков проведем анализ статистических показателей по оттокам и приток ПИИ за последние двадцать лет. При этом под притоком ПИИ нами будет пониматься импорт иностранного капитала, под оттоком - экспорт собственного капитала в зарубежные страны.

Приток ПИИ является показателем благоприятного инвестиционного климата, а также наличия инвестиционно-привлекательных отраслей экономики в стране. Отток ПИИ, в свою очередь свидетельствует о существующей необходимости выхода стран на новые рынки в качестве инвесторов, приобретения зарубежных активов, завоевания конкурентных позиций на мировой арене. Стоит отметить, что в мировом масштабе показатели притоков и оттоков ПИИ должны совпадать, однако в рамках данного анализа могут наблюдаться незначительные погрешности в статистических данных. Данный факт является следствием отсутствия данных по притоку и оттоку некоторых стран, а также несоблюдением рекомендаций ЮНКТАД по подсчету объемов ПИИ (10 и более\% акций в капитале компаний).

С целью определения ключевых импортеров ПИИ, рассмотрим статистику, отражающую динамику входящих мировых инвестиционных потоков (притоков прямых иностранных инвестиций) за 1990-2019 гг. в структуре развитых и развивающихся стран, в том числе стран с переходной экономикой, которая представлена на Рисунке 1.

Из представленных данных видно, что к 2019 г. общий объем притоков ПИИ в сравнении с показателем 1990 г. вырос в 7,5 раз (со 170,1 млрд. долл. США до 1,54 трлн. долл. США). За этот же период мировой ВВП увеличился с 23,4 трлн. долл. США до 87,3 трлн. долл. США в 3,7 раза [12], а экспорт товаров и услуг - 


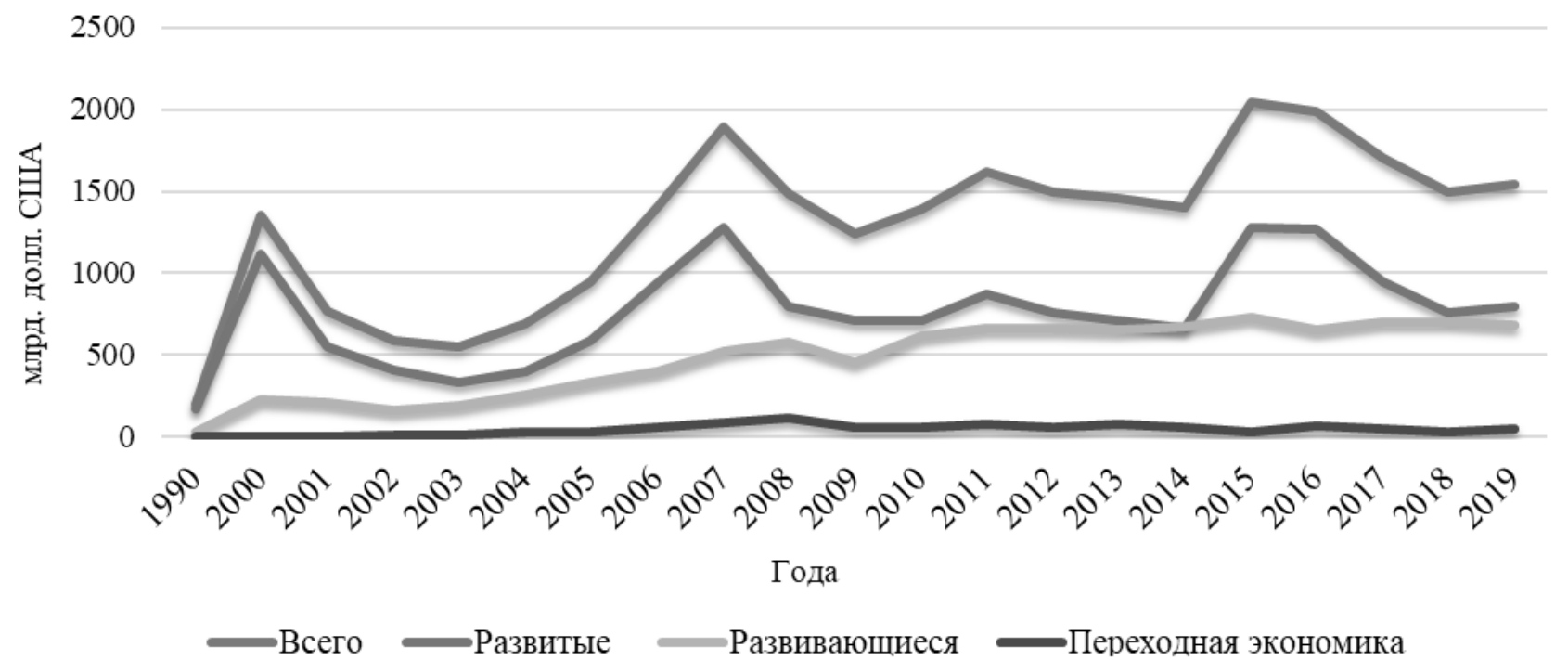

Рис. 1. Динамика изменения прямых иностранных инвестиций (чистый приток, в текущих ценах) за 1990-2019 гг., млрд. долл. США

Источник: Составлено автором на основе [11].

В 5,8 раз с 4,3 трлн. долл. США до 25 трлн. долл. США [13]. Сопоставление темпов роста ПИИ, мирового ВВП и мирового экспорта товаров и услуг позволяет говорить о том, что ПИИ являются мощным инструментом усиления глобальной экономики.

Согласно Рисунку 1 в 2003, 2009 и 2014 годах наблюдалось снижение притока ПИИ (550,6 млрд. долл. США, 1236,1 млрд. долл. США и 1403,0 млрд. долл. США соответственно), что может быть вызвано волатильность мировой экономической ситуации и возникавшими геополитическими рисками. Данный факт, по нашему мнению, свидетельствует о цикличности процессов иностранного инвестирования и подверженности влияния на них глобальных мировых тенденций.

«Отраслевая структура ПИИ претерпела значительные изменения с конца XX к началу XXI века. Если в начале 2000-х годов на долю сферы услуг в накопленных запасах притоков ПИИ приходилось около 40-45\%, то в последние годы этот показатель варьируется в диапазоне 65-70\%» [14]. В настоящее время структура накопленных ПИИ сохраняет тенденцию преобладания доминирующей доли сферы услуг - 61,2\%, на обрабатывающую - 27,8\%, на доля первичного сектора экономики (добыча сырья и сельское хозяйство) - 11\% [15].

Увеличение доли мировых инвестиций в сферу услуг, по нашему мнению, связан со следующими факторами: во-первых, данная тенденция подтверждает динамику роста сферы услуг в мировом ВВП, а во-вторых, является следствием снятия странами барьеров для входа на рынки услуг в сфере информационно-коммуникационных технологий.

Региональная структура мирового притока ПИИ в начале XXI века также претерпела ряд изменений. Так согласно статистике, приведенной в Приложении $Ф$, на долю развитых стран мирового притока ПИИ в 1990 г. приходилось 83,3\% (170,1 млрд. долл. США). Основной объем притока ПИИ приходился на три ключевых географических центра: США и Канаду, ряд европейских стран, а также Республику Корея и Японию.

Однако начиная с 2000-х годов данный показатель претерпел существенное снижение и в 2008 г. составил 53,3\% или 794,3 млрд. долл. США. В 2019 г. суммарный показатель чистого притока ПИИ развитых стран составил чуть больше половины всех поступлений - 51,9\% (800 млрд. долл. США).

Одновременно доля развивающихся стран в совокупности со странами с переходной экономикой за последние двадцать лет существенно выросла с 17,4\% в 2000 г. до 52,2\% в 2014 г. (с 35,3 млрд. долл. США до 734,3 млрд. долл. США), а относительно показателя 1990 г.- количество привлеченных ПИИ выросло в 20 раз. В 2019 г. данный показатель составил чуть меньше $1 \frac{1}{2}$ всех входящих прямых инвестиций $-47,9 \%$ или 739,7 млрд. долл. США.

Выборочно представим статистику по ряду развитых и развивающихся стран за период с 1990 по 2019 года, 
Таблица 1. Основные страны-реципиенты прямых иностранных инвестиций 1990-2019 гг. (млрд. долл. США).

\begin{tabular}{|c|c|c|c|c|c|c|c|c|}
\hline & Страна & 1990 & 2000 & 2008 & 2014 & 2017 & 2018 & 2019 \\
\hline \multirow{8}{*}{ Развитые } & США & 48,4 & 74,4 & 306,4 & 201,7 & 277,3 & 253,6 & 246,2 \\
\hline & Великобритания & 30,4 & 115,3 & 92,2 & 24,6 & 101,2 & 65,3 & 59,1 \\
\hline & Нидерланды & 11,0 & 63,8 & 6,7 & 45,0 & 60,4 & 114,3 & 84,2 \\
\hline & Германия & 2,9 & 198,3 & 8,1 & 3,2 & 60,3 & 73,5 & 36,3 \\
\hline & Франция & 16,5 & 27,5 & 37,6 & 2,6 & 24,8 & 38,1 & 33,9 \\
\hline & Сингапур & 5,5 & 14,7 & 11,8 & 73,2 & 83,6 & 79,7 & 92,0 \\
\hline & Япония & 1,8 & 8,3 & 24,4 & 12,0 & 10,9 & 9,8 & 14,5 \\
\hline & Республика Корея & 1,0 & 11,5 & 11,2 & 9,2 & 17,9 & 12,2 & 10,6 \\
\hline \multirow{8}{*}{ Развивающиеся } & Китай & 7,9 & 95,3 & 174,6 & 247,7 & 250,1 & 252,8 & 219,7 \\
\hline & Индия & 0,2 & 3,5 & 47,1 & 34,5 & 39,9 & 42,1 & 50,5 \\
\hline & Индонезия & - & - & 9,3 & 21,8 & 20,5 & 20,5 & 23,4 \\
\hline & Малайзия & 2,6 & 3,7 & 7,1 & 10,8 & 9,3 & 7,6 & 7,6 \\
\hline & Таиланд & 2,5 & 3,4 & 8,0 & 4,8 & 6,6 & 10,4 & 4,1 \\
\hline & Вьетнам & 0,2 & 1,2 & 9,5 & 9,2 & 14,1 & 15,5 & 16,1 \\
\hline & Филиппины & 0,5 & 2,2 & 1,5 & 5,2 & 8,7 & 6,6 & 5,0 \\
\hline & Бразилия & 1,0 & 32,7 & 45,0 & 63,8 & 66,5 & 59,8 & 71,9 \\
\hline \multirow{5}{*}{ Показатели } & Общий объем притоков ПИИ & 132,4 & 655,8 & 800,5 & 769,3 & 1052,1 & 1061,8 & 975,1 \\
\hline & Объем притоков ПИИ развитых стран & 117,5 & 513,8 & 498,4 & 371,5 & 636,4 & 646,5 & 576,8 \\
\hline & Доля развитых стран в общем притоке ПИИ (\%) & 57,6 & 37,9 & 33,4 & 25,9 & 37,4 & 43,2 & 37,5 \\
\hline & Объем притоков ПИИ развивающихся стран & 13,9 & 109,3 & 257,1 & 334,0 & 349,2 & 355,5 & 326,4 \\
\hline & Доля развивающихся стран в общем притоке ПИИ (\%) & 6,8 & 8,0 & 17,3 & 23,3 & 20,5 & 23,7 & 21,2 \\
\hline
\end{tabular}

Источник: Рассчитано автором на основе [11].

которые привлекли в свою экономику значительные объемы притоков ПИИ (Таблица 1).

За период 1990-2019гг. совокупный объем притоков ПИИ вышеприведенных стран вырос в 7,4 раза со 132,4 млрд. долл. США до 975,1 млрд. долл. США. Доля этих стран в общем объеме притоков ПИИ на протяжении всего временного диапазона была более половины и варьировалась в диапазоне 55-60\%.

Основными странами-реципиентами инвестиционных потоков стали такие развитые государства, как Соединенные Штаты Америки, ряд европейских стран - Соединённое Королевство Великобритании и Северной Ирландии, Королевство Нидерландов, Федеративная Республика Германии, Французская Республика, и три азиатские страны - Республика Сингапур, Япония и Республика Корея, а также развивающиеся страны Азии, такие как Китайская Народная Республика, Республика Индия, Республика Индонезия, Малайзия, Королевство Таиланд, Социалистическая Республика Вьетнам, Республика Филиппины и одна из стран Латинской Америки - Федеративная Республика Бразилия.

Объем привлеченных ПИИ вышеупомянутых развитых стран вырос в 5 раз со 117,5 млрд. долл. США в 1990 г. до 576,8 млрд. долл. США в 2019 г. Стоит отметить, что, хотя количественные объемы привлеченных ПИИ этих стран росли, доля в совокупном объеме уменьшалась из года в год (с 57,6\% в 1990 г. до 37,5\% в 2019 г.).

Доля приведенных в Таблице 1 развитых стран в совокупном объеме привлеченных ПИИ развитых стран на протяжении 1990-2019 гг. не опускалась ниже отметки 55\%, и в 2019 г. составила $72 \%$.

Наибольший интерес для нас представляют развивающиеся страны, чьи объемы привлеченных ПИИ выросли в 25 раз с 13,9 млрд. долл. США в 1990 г. до 326,4 млрд. долл. США в 2019, с 6,8\% до 21,2\% совокупного притока ПИИ. Особую роль в привлечении ПИИ сыграли страны Азии (в первую очередь Китай, Индия, Индонезия, Малайзия, Таиланд, Филиппины), чья доля в совокупном объеме притока ПИИ развивающихся стран на протяжении последних тридцати лет не снижалась менее $60 \%$ и в настоящее время составляет $69,3 \%$.

С целью определения ключевых экспортеров ПИИ, далее рассмотрим динамику исходящих мировых инвестиционных потоков (оттоков прямых иностранных инвестиций) за 1990-2019гг. в структуре развитых 
Таблица 2. Основные страны-экспортеры прямых иностранных инвестиций 1990-2019 гг. (млрд. долл. США).

\begin{tabular}{|c|c|c|c|c|c|c|c|c|}
\hline & Страна & 1990 & 2000 & 2008 & 2014 & 2017 & 2018 & 2019 \\
\hline \multirow{8}{*}{ Развитые } & США & 30,9 & 142,6 & 308,3 & 333,0 & 300,4 & 90,6 & 124,9 \\
\hline & Великобритания & 17,9 & 232,7 & 198,2 & 151,3 & 117,5 & 41,5 & 31,5 \\
\hline & Нидерланды & 14,3 & 75,6 & 68,5 & 59,4 & 46,9 & 18,8 & 124,7 \\
\hline & Германия & 24,2 & 57,0 & 71,5 & 84,0 & 104,0 & 78,8 & 98,7 \\
\hline & Франция & 38,3 & 161,9 & 103,2 & 49,9 & 35,6 & 105,6 & 38,6 \\
\hline & Сингапур & 2,0 & 6,8 & 8,0 & 52,4 & 48,8 & 29,7 & 33,2 \\
\hline & Япония & 50,7 & 31,5 & 128,0 & 130,8 & 164,7 & 143,2 & 226,6 \\
\hline & Республика Корея & 1,2 & 4,8 & 19,5 & 28,0 & 34,1 & 38,2 & 355 \\
\hline \multirow{10}{*}{ Развивающиеся } & Китай & 8,4 & 61,6 & 114,5 & 150,0 & 256,9 & 244,0 & 188,8 \\
\hline & Индия & - & - & 21,2 & 11,8 & 11,1 & 11,5 & 12,1 \\
\hline & Индонезия & - & - & 5,9 & 7,0 & 2,1 & 8,0 & 3,4 \\
\hline & Малайзия & 0,1 & 2,0 & 14,9 & 16,4 & 5,6 & 5,1 & 6,3 \\
\hline & Таиланд & 0,2 & 0,2 & 0,3 & 5,6 & 16,9 & 18,5 & 11,9 \\
\hline & Вьетнам & - & - & 0,3 & 1,2 & 0,5 & 0,6 & 0,5 \\
\hline & Филиппины & 0,2 & 0,3 & 2,2 & 6,3 & 1,7 & 0,7 & 0,7 \\
\hline & Бразилия & 0,6 & 2,2 & 20,4 & 3,2 & 19,0 & 16,3 & 15,5 \\
\hline & Саудовская Аравия & 0,7 & 1,6 & 3,5 & 5,3 & 7,2 & 22,9 & 13,1 \\
\hline & Объединенные Арабские Эмираты & 0,3 & 0,4 & 15,8 & 11,7 & 14,0 & 15,0 & 15,9 \\
\hline \multirow{5}{*}{ Показатели } & Совокупный объем оттоков ПИИ & 159,1 & 638,6 & 795,9 & 774,3 & 886,6 & 798,4 & 1176,5 \\
\hline & Объем оттоков ПИИ развитых стран & 148,6 & 570,3 & 596,9 & 555,8 & 551,6 & 455,8 & 908,3 \\
\hline & Доля развитых стран в общем оттоке ПИИ (\%) & 60,9 & 49,0 & 34,8 & 43,9 & 34,4 & 46,2 & 69,1 \\
\hline & Объем оттоков ПИИ развивающихся стран & 10,5 & 68,3 & 199,0 & 218,5 & 335,0 & 342,6 & 268,2 \\
\hline & Доля развивающихся стран в общем оттоке ПИИ (\%) & 4,3 & 5,8 & 11,6 & 17,2 & 20,9 & 34,7 & 20,4 \\
\hline
\end{tabular}

Источник: Рассчитано автором на основе [11].

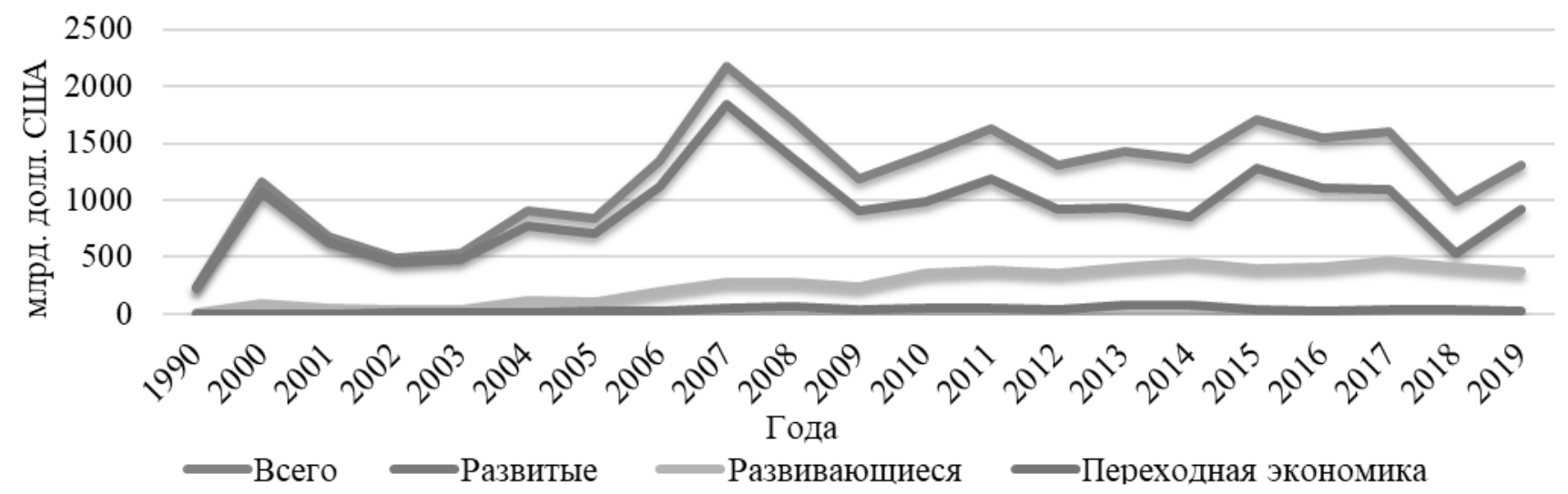

Рис. 2. Изменение уровня прямых иностранных инвестиций (чистый отток, в текущих ценах) стран по уровню развития за 1990-2019 гг., млрд. долл. США

Источник: Составлено автором на основе [11].

и развивающихся стран, в том числе стран с переходной экономикой, которая представлена на Рисунке 2.

Из представленных данных видно, что к 2019 г. общий объем притоков ПИИ в сравнении с показателем 1990 г. вырос в 5,4 раз (с 243,8 млрд. долл. США до 1,31 трлн. долл. США).
Традиционно ключевыми странами-инвесторами на протяжении последних 30 лет остаются развитые страны, в частности большая часть приходится на европейские страны, однако их доля постепенно снижается. Так, в 1990 г. на них приходился почти весь экспорта ПИИ - 94,6\% (230,7 млрд. долл. США), однако начиная с 2010 г. данный показатель составил чуть 
Таблица 3. Мировые объемы сделок по слияниям и поглощению (млрд. долл. США)

\begin{tabular}{|l|l|l|l|l|l|l|l|}
\hline Год & $\mathbf{1 9 9 0}$ & $\mathbf{2 0 0 0}$ & $\mathbf{2 0 0 8}$ & $\mathbf{2 0 1 4}$ & $\mathbf{2 0 1 7}$ & $\mathbf{2 0 1 8}$ & $\mathbf{2 0 1 9}$ \\
\hline Объемы сделок М\&А & 54,0 & 362,3 & 307,5 & 395,4 & 377,6 & 412,7 & 370,1 \\
\hline Мировой объем притоков ПИИ & 204,0 & 1356,6 & 1490,0 & 1403,0 & 1700,5 & 1495,2 & 1539,8 \\
\hline Доля М\&А в общем объеме ПИИ (\%) & 26,5 & 27 & 21 & 28 & 23 & 28 & 24 \\
\hline
\end{tabular}

Источник: Рассчитано автором на основе [16].

более 2/3 всего экспорта инвестиций и в 2019 г. достиг доли 69,7\% (916,8 млрд. долл. США).

Иная картина наблюдается в динамике поступления инвестиций из развивающихся стран. Данные приведенной статистики подтверждают, что начиная с 2010 г. суммарная доля развивающихся стран в совокупности со странами с переходной экономикой в мировом экспорте капитала значительно увеличилась (с 5,3\% в 1990 г. до 29,2\% в 2010 г.), а объем исходящих инвестиций увеличился более чем в 30 раз с 13,1 млрд. долл. США до 407,5 млрд. долл. США. В 2019 г. на долю стран с развивающейся и переходной экономикой пришлось около трети мирового экспорта инвестиций (30,2\% или 396,8 млрд. долл. США).

Выборочно представим статистику по ряду развитых и развивающихся стран за период с 1990 по 2019 года, экспорт инвестиций которых в экономики других стран показал наилучшую динамику (Таблица 2).

За период 1990-2019 гг. совокупный объем оттоков ПИИ вышеприведенных стран вырос в 7,3 раза со 159,4 млрд. долл. США до 975,1 млрд. долл. США. Доля этих стран в общем объеме оттоков ПИИ на протяжении всего временного диапазона была более половины и варьировалась в диапазоне 50-80\%.

Основными странами-экспортерами инвестиций стали такие развитые страны как: Соединенные Штаты Америки, ряд европейских стран - Соединённое Королевство Великобритании и Северной Ирландии, Королевство Нидерландов, Федеративная Республика Германии, Французская Республика, и три азиатские страны - Республика Сингапур, Япония и Республика Корея, что полностью дублирует перечень стран-реципиентов ПИИ. В списке основных развивающихся стран-экспортеров инвестиций по сравнению с развивающимися странами-реципиентами инвестиций мы выявили ряд изменений. Ими стали: Китайская Народная Республика, Республика Индия, Республика Индонезия, Малайзия, Королевство Таиланд, Социалистическая Республика Вьетнам, Республика Филиппины, Федеративная Республика Бразилия, а также к ним присоединились Королевство Саудовская Аравия и Объединенные Арабские Эмираты.
Объем экспортированных иностранных инвестиций вышеупомянутых развитых стран вырос в 6 раз со 148,6 млрд. долл. США в 1990 г. до 908,3 млрд. долл. США в 2019 г. Количественные объемы оттоков прямых иностранных инвестиций этих стран росли, однако доля в совокупном объеме уменьшалась из года в год (с 60,9\% в 1990 г. до 46,2\% в 2018 г.). Доля приведенных в Таблице 27 развитых стран в совокупном объеме исходящих прямых иностранных инвестиций в 2019 г. составила $69,1 \%$.

Объемы оттока ПИИ вышеприведенных развивающихся стран, выросли в 26 раз с 10,5 млрд. долл. США В 1990 г. до наилучшего показателя 342,6 млрд. долл. США в 2018, с 4,3\% до 34,7\% совокупного оттока ПИИ. В 2019 г. данный показатель снизился и составил 20,4\%.

Особую роль в экспорте ПИИ сыграли первую очередь Китай, Малайзия, Бразилия, в последние годы усилились позиции арабских стран - Саудовской Аравии и ОАЭ. Доля последних в совокупном объеме оттока ПИИ всех развивающихся стран на протяжении последних тридцати лет не снижалась менее 70\% и в настоящее время составляет 71,9\%. Таким образом прослеживается тренд в усилении развивающимися странами-инвесторами своих позиций.

Тенденция, присущая началу XXI века направленности потоков прямых иностранных инвестиций из развитых стран в развитые (Запад-Запад) и из развивающихся стран в развитые (Юг-Запад) за последние два десятилетия существенно поменялась. Теперь можно говорить об усилении динамики направленности потоков ПИИ из развитых в развивающиеся (Запад-Юг) и из развивающихся в развивающиеся (Юг-Юг).

Среди различных форм прямых иностранных инвестиций особого внимания заслуживают сделки по слияниям и поглощениям (mergers \& acquisitions - M\&A), занимающие более четверти всех потоков ПИИ (Таблица 3). Сделки по М\&A отражают стремления бизнеса расширить свои позиции на мировой арене - масштабировать свои мощности.

По данным американского Института слияний, поглощений и альянсов (Institute for Mergers, Acquisitions 


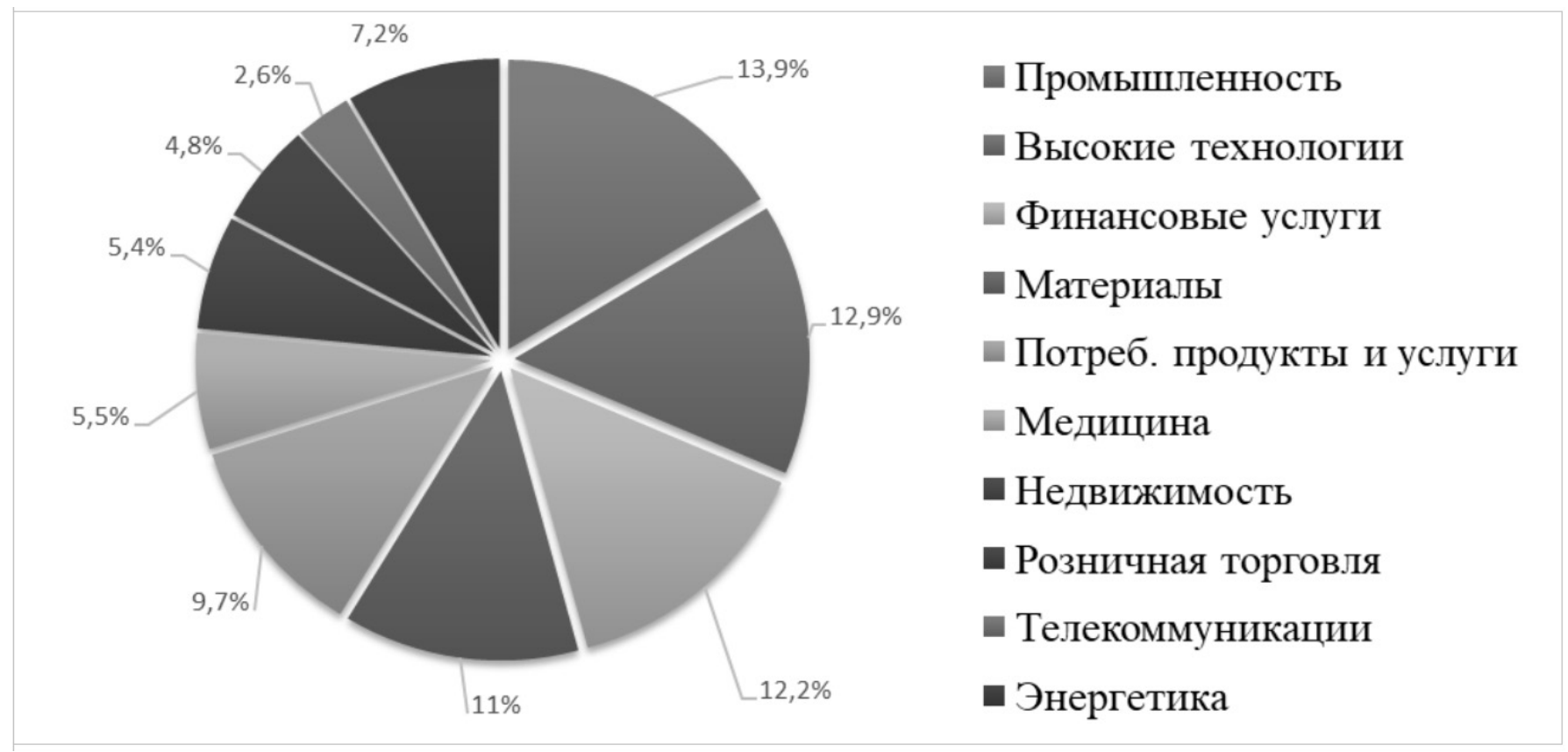

Рис. 3. Количество слияний и поглощений по отраслям (1985-2016 гг.,\%) Источник: Составлено автором на основе [17].

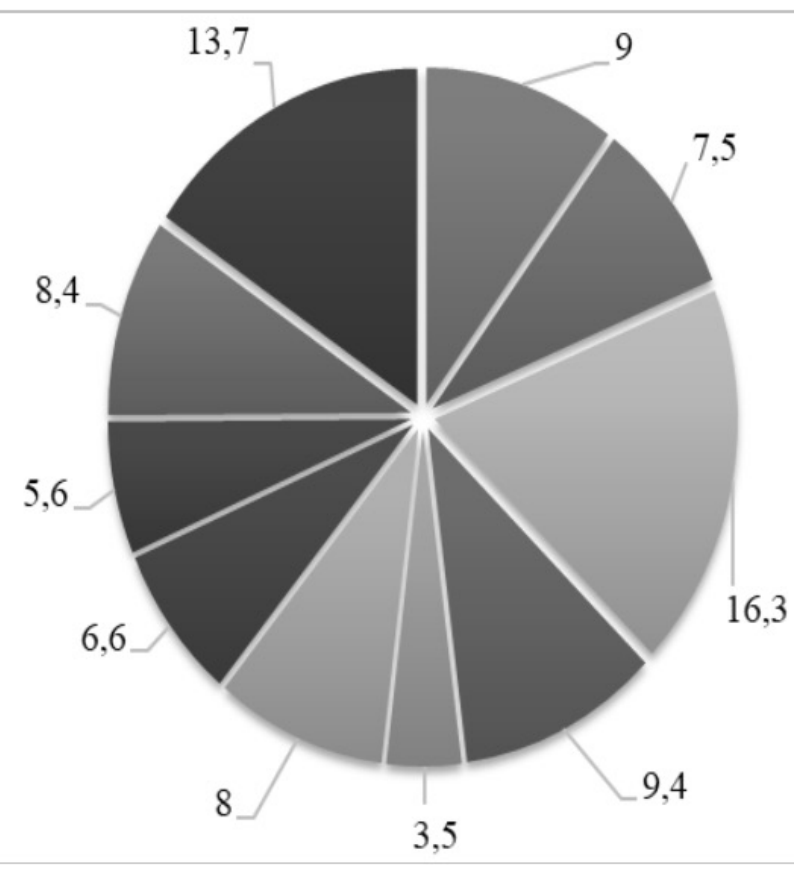

промышленность

шысокие технологии

шинансовые услуги

- Материалы

- Потреб. продукты и услуги

- Медицина

- Недвижимость

- Розничная торговля

- Телекоммуникации

- Энергетика

Рис. 4. Объем сделок по слиянию и поглощений по отраслям (1985-2016 гг.,\%) Источник: Составлено автором на основе [17]. 
Таблица 4. Стоимостные показатели сделок по слияниям и поглощению по отраслям, 1985-2019 гг. (млрд. долл. США).

\begin{tabular}{|l|l|l|l|l|l|l|l|l|l|}
\hline Отрасли/года & $\mathbf{1 9 8 5}$ & $\mathbf{1 9 9 0}$ & $\mathbf{2 0 0 0}$ & $\mathbf{2 0 0 8}$ & $\mathbf{2 0 1 4}$ & $\mathbf{2 0 1 7}$ & $\mathbf{2 0 1 8}$ & $\mathbf{2 0 1 9}$ \\
\hline Финансовые услуги (объем) & 1,3 & 4,9 & 23,5 & 36,5 & 9,4 & 8,7 & 10,0 & 12,6 \\
\hline Количество сделок (ед.) & 247 & 979 & 1041 & 1107 & 914 & 803 & 718 & 619 \\
\hline Энергетическая промышленность (объем) & 6,4 & 6,3 & 36,6 & 46,0 & 57,3 & 46,4 & 57,3 & 51,7 \\
\hline Количество сделок (ед.) & 225 & 794 & 2278 & 3570 & 3313 & 3502 & 3549 & 3204 \\
\hline $\begin{array}{l}\text { Телекоммуникации } \\
\text { и радиоэлектроника (объем) }\end{array}$ & 0,4 & 6,3 & 109,1 & 21,1 & 24,7 & 11,0 & 11,9 & 7,7 \\
\hline Количество сделок (ед.) & 41 & 304 & 1315 & 1001 & 716 & 760 & 786 & 712 \\
\hline $\begin{array}{l}\text { Фармацевтическая промышленность } \\
\text { (объем) }\end{array}$ & 1,0 & 1,1 & 22,2 & 13,0 & 51,0 & 10,4 & 24,2 & 35,0 \\
\hline Количество сделок (ед.) & 32 & 175 & 437 & 888 & 906 & 1130 & 1376 & 1253 \\
\hline $\begin{array}{l}\text { Создание программного обеспечения } \\
\text { (объем) }\end{array}$ & 0,1 & 0,3 & 23,3 & 9,8 & 18,2 & 16,1 & 21,8 & 20,6 \\
\hline Количество сделок (ед.) & 29 & 266 & 5616 & 2809 & 2952 & 3530 & 3913 & 3656 \\
\hline
\end{tabular}

Источник: Рассчитано автором на основе [17].

and Alliances - IMAA) с 1985-2016 гг. большее количество сделок происходило в промышленном секторе (126 тыс. сделок на 6,1 трлн. долл. США). Второе место по количеству сделок занимают сделки в сфере высоких технологий (118 тыс. сделок на 5,0 трлн. долл. США). Сделки в сфере финансовых услуг занимают третье место (111 тыс. сделок на 10,8 трлн. долл. США (Рисунок 3).

Что же касается стоимостных показателей сделок слияний и поглощений, то наибольших показателей в совокупности с 1985-2016 гг. достиг сектор финансовых услуг - 10,8 трлн. долл. США., энергетика 9,0 трлн. долл. США., материалы - 6,2 трлн. долл. США., промышленность - 5,9 трлн. долл. США., телекоммуникации - 5,5 трлн. долл. США., медицина - 5,3 трлн. долл. США., высокие технологии - 5,0 трлн. долл. США. (Рисунок 4).

Ключевыми отраслями, в которых за период с 19852019 г. произошло значительное количество сделок по слиянию и поглощению в больших стоимостных объемах являлись: финансовые услуги, нефтегазовая промышленность, телекоммуникации и радиоэлектроника, фармацевтическая промышленность, создание программного обеспечения (Таблица 4).
Подводя итог, отметим, что представленные данные позволили нам сделать вывод, что наибольшую активность в период с 2000-2014 гг. в рамках сделок по слиянию и поглощению компаниями своих капиталов продемонстрировали три отрасли: энергетическая промышленность, телекоммуникации и радиоэлектроника, а также услуги по созданию программного обеспечения. В последние же годы большинство сделок происходят в сфере энергетического оборудования, создания ПО и фармацевтической промышленности.

При этом основными странами-реципиентами и странами-экспортерами потоков прямых иностранных инвестиций за последние два десятилетия являлись развитые страны, среди которых США, четыре европейских страны - Великобритания, Нидерланды, Германия, Франция, три азиатских страны - Сингапур, Япония и Корея, а также ряд развивающихся стран Восточной, Южной и Юго-Восточной Азии: Китай, Индия, Индонезия, Малайзия, Таиланд, Вьетнам, Филиппины.

Развивающиеся страны из года в год наращивали свой потенциал и к настоящему времени смогли преломить вектор направленности потоков прямых иностранных инвестиций в свою пользу.

\section{ЛИТЕРАТУРА}

1. Инновационный менеджмент: учебник / Ильенкова С.Д [и др.]; под ред. Ильенковой С.Д. — 3-е изд. — М.: ЮНИТИ, 2007

2. Зенин И.А. «0 концепции глобальной лицензии как инструменте управления правами на объекты интеллектуальной собственности в цифровой среде» / Право интеллектуальной собственности. 2015. № 3. С. 5.

3. Тюрина В.Ю., Ипполитова А.А. Маркетинговая стратегия как фактор развития трансфера и коммерциализации инновационных технологий / Известия Саратовского университета. Новая серия. Серия Экономика. Управление. Право. 2015. № 2 (15). С. 163.

4. Основы международной торговли: Учеб. пособие / Под ред. Козака Ю.Г., Логвиновой Н.С.— ЦУЛ, 2005. С. 113 
5. Международный менеджмент: Учебник для вузов / Пол ред. С.Э. Приноварова. - СПб.: Питер, 2000. С. 506

6. «Руководство по платежному балансу и международной инвестиционной позиции» MBФ — 6-е издание [Электронный pecypc]. — URL: https://www. imf.org/external/pubs/ft/bop/2007/pdf/bpm6.pdf

7. Основы внешнеэкономической деятельности: региональный аспект: учебно-методический комплекс / Толмачёв А.С. БФУ им. И. Канта (Балтийский федеральный университет им. И. Канта)

8. OECD Benchmark Definition of Foreign Direct Investment — 4th ed. [Электронный ресурс].— URL: https://www.oecd.org/daf/inv/investments C. 11

9. ЮНКТАД (2019b). Отчет О Мировых Инвестициях 2019: Особые Экономические Зоны. Издание Организации Объединенных Наций. Е. 19. .II. D. 12.

10. Иностранные инвестиции и современное предпринимательство: учебное пособие / К.Ю. Багратуни, М.В. Данилина — Москва: РУСАЙНС, 2018. — 148 с. — С. — 61.

11. Электронная база UNCTADStat [Электронный ресурс].— URL: https://unctadstat.unctad.org/wds/TableViewer/tableView.aspx

12. Глобальный ВВП мира. IFinance / [Электронный ресурc].— URL: http://global-finances.ru/vvp-mira-po-godam/

13. Мировой экспорт товаров и услуг. IFinance / [Электронный ресурс].— URL: http://global-finances.ru/mirovoj-eksport-po-godam/

14. UNCTAD. World Investment Report 2019. - N.-Y., Geneva, UNCTAD, 2019

15. World Development Indicators / World DataBank. [Электронный ресурс]. URL: http://databank.worldbank.org/data/reports.aspx?source=worlddevelopmentindicators

16. Электронная база IMAA [Электронный ресурс].— URL: https://imaa-institute.org/mergers-and-acquisitions-statistics/

17. Электронная база IMAA [Электронный ресурс]. — URL: https://imaa-institute.org/m-and-a-by-industries/

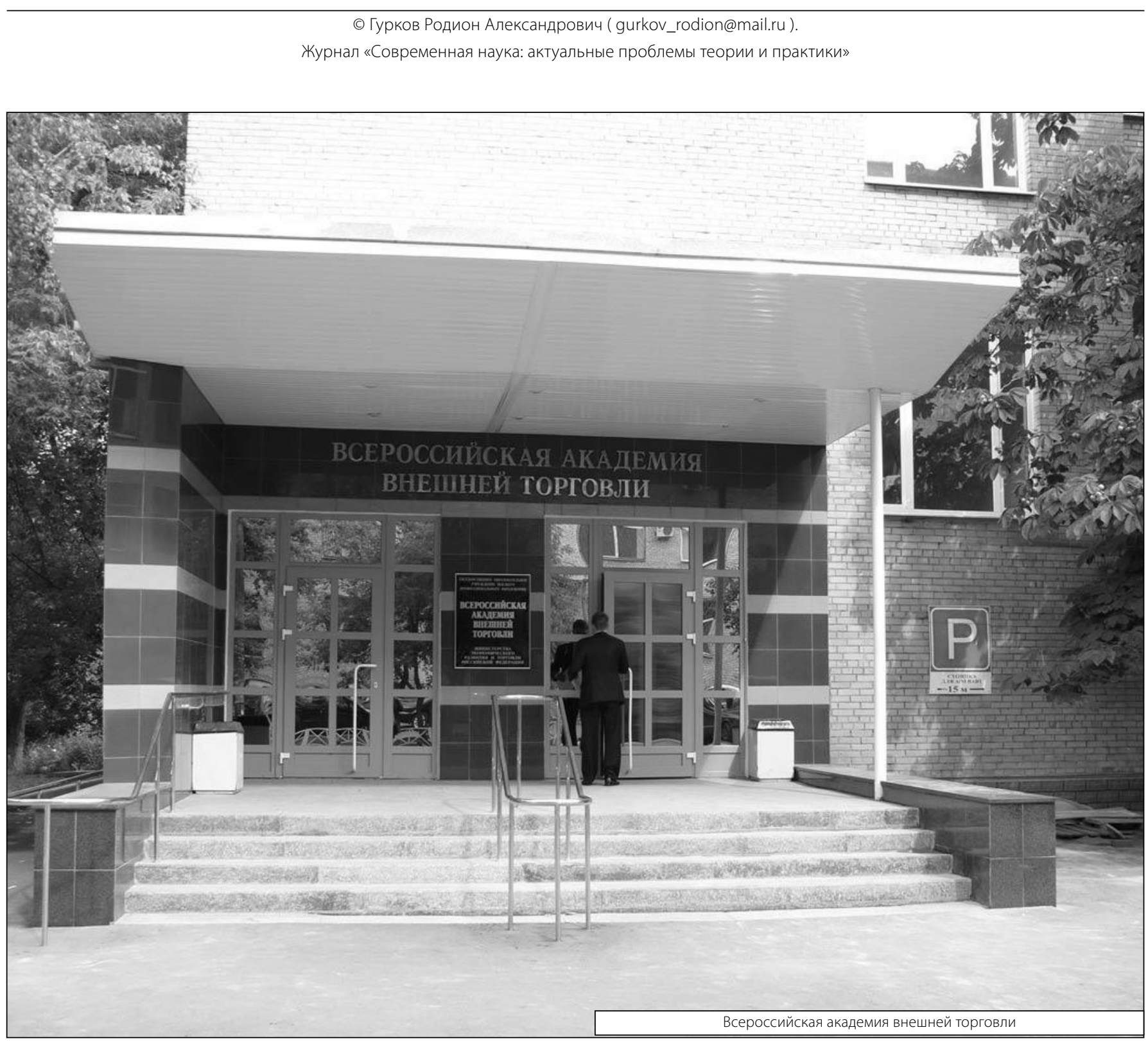

